\title{
Evaluation of physico-chemical properties, time of hardening and draining of an endodontic sealer added to mta in different proportions
}

\begin{abstract}
Wanderson Carvalho de Almeida, ${ }^{1}$ Barbara Manuelle de Carvalho Barros, ${ }^{2}$ Isabelle de Meneses Aragão Ramos, ${ }^{2}$ Maria Ângela Arêa Leão Ferraz, ${ }^{1,2}$ Carlos Alberto Monteiro Falcão $0^{1,2}$

${ }^{1}$ School of Dentistry, State University of Piauí (UESPI), Teresina, PI, Brazil

${ }^{2}$ School of Dentistry, UNINOVAFAPI University Center, Teresina, PI, Brazil

- Conflicts of interest: none declared.

Abstract

Objective: evaluate the hardening time and flow of AH-PLUS and MTA cement in the proportions of $10 \%, 20 \%$ and $30 \%$ in order to add the ability to stimulate the deposition of hard tissue. Material and Methods: For the flow test, $0.5 \mathrm{ml}$ of cement was deposited on a glass plate and another plate was added with an additional charge, after 10 minutes the charge was removed and the diameter of the circle formed by the cement was measured with a digital compass. For the hardening time, cylindrical molds filled with the tested cement were used, kept inside a kiln and Gillmore needle tests were performed on the material at 60 second intervals until the marks were not visible on the surface of the tested cement. Results: In the flow rate, the values obtained were: $41.1 \mathrm{~mm}(10 \% \mathrm{MTA}), 32.86 \mathrm{~mm}(20 \% \mathrm{MTA}), 21.91 \mathrm{~mm}(30 \% \mathrm{MTA}), 24.41 \mathrm{~mm}$ AHPlus $^{\circledR}$ and $26.47 \mathrm{~mm} \mathrm{MTA}$ Fillapex ${ }^{\circledR}$. The hardening time found in this survey was 1631 'in proportion (10\% MTA), 628.4 in proportion (20\% MTA), 567 ' in proportion ( $30 \%$ MTA), 767 in AH Plus and Fillapex MTA did not. took prey within 6 weeks. Conclusion: it was concluded that the addition of $10 \%, 20 \%$ and $30 \%$ of MTA to AH Plus did not change the flow properties and the established time.
\end{abstract}

Keywords: Endodontic; Endodontic cement; Flow; Hardening time.

\section{Introduction}

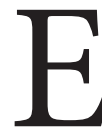
ndodontics is the field of dentistry that studies the pulp cavity morphology, the physiology and pathology of the dental pulp as well as the prevention and treatment of pulp alterations and their repercussions on the periodontal tissues. ${ }^{1}$ Obtaining a root canal means filling it to the fullest extent with an inert or antisetic material, hermetically sealing it, not interfering and preferably stimulating the apical and periapical repair process. ${ }^{2}$ Obtaining an airtight seal after proper root canal cleaning and mo-deling is one of the keys to achieving long-term endodontic treatment success. ${ }^{3}$ The flow property of obturator cement is evaluated by the methodology proposed by ANSI/ADA Standard $\mathrm{N}^{\circ} 57$. The flow of obturator sealers consists in their ability to penetrate irregularities, root canal system branches and dentinal tubules. The greater the fluidity of the material, the greater its penetration capacity, however, there is also a greater chance of material leakage and, consequently, damage to the periapical tissue. $^{4}$

Sealer setting time is also evaluated using the methodology proposed by ANSI/ADA Standard $\mathrm{N}^{\circ} 57$ for sealing endodontic materials. This property calculates the time interval available for root canal obturation that may be interfered by factors such as temperature, powder to liquid ratio, particle size, environment and $\mathrm{pH}$. According to Alan et al. ${ }^{5}$ that time should not be long enough to impair clinical conduct, as that may cause cement deterioration, favoring the penetration of irritants and the release of possible toxic products, nor should it be short so that the work is completed properly. AH Plus ${ }^{\circledR}$ is a sealer marketed in 2 pastes, the paste A consisting of Bisphenol-A epoxy resin, Bisphenol-Fepoxy resin, calcium tungstate, silica,zirconium oxide and iron oxide pigments. Paste B contains dibenzyl diamine, aminoadamantane, tricyclodecanediamine, calcium tugstenate, zirconium oxide, silica and silicone oil. ${ }^{6}$ Thus, sealer handling should be done by mixing the same volume of paste A and B (1:1) with a metal spatula to achieve homogeneous consistency. This sealer has good flow, working time of 4 hours at $23^{\circ} \mathrm{C}$ and setting time is 8 hours at $37^{\circ} \mathrm{C}$. However, it has no mineralized tissue inducing potential. ${ }^{7}$

MTA is a mixture of hydrophilic powder consisting of tricalcium silicate, tricalcium oxide, silicate oxide and tricalcium aluminate, ${ }^{8,9,10}$ fine particles that harden in the presence of moisture. ${ }^{11,12}$ The hardening process of MTA can be described as a hydration of its silicates in which $\mathrm{Ca} 2 \mathrm{SiO} 4$ is responsible for the development of mechanical strength. ${ }^{13,14}$ In this process, ions dissolve initially from the anhydrous material which induces the formation of calcium silicate hydrate (CSH) and calcium hydroxide $(\mathrm{CH}) 14$, leading to the crystallization of hydrates with a tangled structure that gives resistance to material. ${ }^{15}$ Several laboratory and in vivo research involving cell-tissue interactions with MTA demonstrate 
its biocompatibility. ${ }^{16,17}$ However, changes in its composition and formulation with its mineral aggregates and the emergence of new materials propose to overcome some adversities in their physicochemical characteristics, ${ }^{18,19}$ in which they stand out: sandy consistency (makes the material handling difficult and its application) 20 dispersion poor, high porosity, long gripping time, ${ }^{21}$ tooth and gum blackening ${ }^{22,23}$ and high cost. ${ }^{24}$

Although it does not contain calcium hydroxide, after hardening of the MTA, calcium oxide is formed, which can react with tissue fluids to produce calcium hydroxide. After contact with pulp tissue, MTA has some structures that are similar to calcium crystals found in calcium hydroxide. These attract fibronectin, which is generally responsible for cell adhesion and differentiation, as does calcium hydroxide ${ }^{25}$ the presence of calcium hydroxide makes highly alkaline cement ( $\mathrm{pH} 12.5) .{ }^{26} \mathrm{In}$ addition to these characteristics, MTA has a desirable osteoinductive property. ${ }^{10}$ MTA powder, when mixed with water, results in the formation of a colloidal gel that hardens within 3 to 4 hours. ${ }^{8,9}$ The addition in different proportions of MTA to AH Plus aims to add the ability to stimulate hard tissue deposition to AH Plus, promoting a better biological response without changing its physicochemical properties. The present work aims to evaluate the flow and hardening time of $\mathrm{AH}$ Plus resin cement plus MTA in different proportions.

\section{Material and Methods}

AH Plus ${ }^{\circledR}$ cement (Dentsply De Trey, Konstanz, Germany) was used. The composition of which according to the manufacturer is: "Paste A: bisphenol-A epoxy resin, bisphenol-F epoxy resin, calcium tungstate, zirconium oxide, silica, iron oxide pigments; Paste B: Aminoadamantane, Dibenzyldiamine; tricyclodecaneDiamine; calcium tungstate; zirconium oxide, silica, silicone oil". The composition of MTA is a mixture of hydrophilic powder consisting of tricalcium silicate, tricalcium oxide, silicate oxide and tricalcium aluminate. The materials tested were AH Plus cement added to MTA in different proportions (Table 1).

Table 1. Experimental Groups

\begin{tabular}{l|l}
\hline \multicolumn{1}{c|}{ GROUPS } & \multicolumn{1}{c}{ SEALERS } \\
\hline GROUP 1 & AH Plus $^{\circledR}+10 \%$ of MTA \\
\hline GROUP 2 & AH Plus $^{\circledR}+20 \%$ of MTA \\
\hline GROUP 3 & AH Plus $^{\circledR}+30 \%$ of MTA \\
\hline GROUP 4 & AH Plus $^{\circledR}$ \\
\hline GROUP 5 & MTA Fillapex $^{\circledR}$ \\
\hline
\end{tabular}

The cements were manipulated according to the groups tested, using precision scales followed by spatulation with the aid of a flexible spatula number 24 on a glass plate. Flow was evaluated using the methodology proposed by ANSI/ADA Standard № 57 for sealing endodontic materials. The test was conducted by splattering the cement according to the formulation of the tested groups and, with the aid of a glass Luer syringe $(3.0 \mathrm{ml})$ adapted to always receive the same volume of manipulated cement $(0.5 \mathrm{ml})$.

After handling the AH Plus cement associated with the MTA in the proportions of $10 \%, 20 \%$ and $30 \%$ and obtaining a volume of $0.5 \mathrm{ml}$, these foam were placed in the center of the clean and smooth glass plate of dimensions $10 \times 10 \mathrm{~cm}$. After $180 \pm 5$ seconds of the start of handling, a set consisting of a glass plate and additional load weighing a total of 120 grams was carefully and centrally placed above the obturator cement.

Additional weight was removed 10 minutes after the start of mixing and the largest and smallest diameters of the cement circle were measured with the aid of a digital caliper. The same was done with AH Plus cement in its pure form and with O MTA Fillapex according to the manufacturer's guidelines. Five repetitions were performed for the studied cement, obtaining the arithmetic mean that represents the flow of the material. ${ }^{27}$

\section{Results}

Stainless steel cylindrical molds were made with an internal diameter of $10 \mathrm{~mm}$ and a uniform thickness of $2 \mathrm{~mm}$. The molds were fixed on their external faces, with the aid of utility wax, on a glass plate $1 \mathrm{~mm}$ thick by $25 \mathrm{~mm}$ wide and $75 \mathrm{~mm}$ long. The tested cements were manipulated and placed inside the metal cylinder until they were completely filled. $120 \pm 10$ seconds after the start of mixing, the cement-filled glass-mold plate assembly was placed on a $10 \times 20 \mathrm{~mm}$ by $10 \mathrm{~mm}$ metal grid, conditioned within a hermetically sealed plastic container. The set was kept at a constant temperature of 37 degrees centigrades in a kiln with 95\% relative humidity. The set formed by the specimen/glass slide/ metal cylinder was inside the climate chamber until the end of the test.

After $150 \pm 10$ seconds from the start of mixing, a $100 \mathrm{~g}$ Gillmore needle with a $2.0 \mathrm{~mm}$ active tip was placed vertically on the horizontal surface of the material. The placement of the Gillmore needle over the material was repeated at 60 -second intervals until it no longer caused marks on the tested cement. After obtaining the flow test (Table 2) and hardening time data (Table3), theseweresubmitted to statisticalanalysisusing the non-parametric Mann Whitney test. 
Table 2. Diameters (in $\mathrm{mm}$ ) of the circles obtained during the flow test and the standard deviation of each group.

\begin{tabular}{l|c|c}
\hline \multicolumn{1}{c|}{ Groups } & Average & SD \\
\hline Group 1 & 41.1 & 11.12 \\
\hline Group 2 & 32.86 & 9.83 \\
\hline Group 3 & 21.91 & 4.10 \\
\hline Group 4 & 24.41 & 0.94 \\
\hline Group 5 & 26.47 & 1.93 \\
\hline
\end{tabular}

$\mathrm{P}=0.009 \mathrm{G} 1 \times \mathrm{G} 4 ; \mathrm{P}=0.016-\mathrm{G} 2 \times \mathrm{G} 4 ; \mathrm{P}=0.17-\mathrm{G} 3 \times \mathrm{G} 4 . \mathrm{SD}=$ Standard Deviation.

Table 3. Average hardening time values and the standard deviation of each group.

Hardening Time $(\mathrm{mm})$

\begin{tabular}{l|c|c}
\hline \multicolumn{1}{c|}{ Groups } & Average & SD \\
\hline Group 1 & 1631 & 11 \\
\hline Group 2 & 658.4 & 30.24 \\
\hline Group 3 & 567 & 44 \\
\hline Group 4 & 767 & 15 \\
\hline
\end{tabular}

Group 5*

$\mathrm{P}<0,01$ - G1 x G4; G2 x G4; G3 x G4. SD = Standard Deviation (value of $P<0,01$ in all comparisons: $\mathrm{G} 1 \times \mathrm{G} 4 ; \mathrm{G} 1 \times \mathrm{G} 4 ; \mathrm{G} 3 \times \mathrm{G} 4$ )

*The waiting period for polymerization of this group exceeded 6 weeks.

\section{Discussion}

The flow of a filling cement is an important factor in the clinical performance of the material, as it interferes with its ability to penetrate small irregularities in the dentin and lateral channels. ${ }^{26}$ According to Lara, ${ }^{28}$ the flow determination can be performed by several techniques: viscosity, penetrability, flatness and extrusion. The present work used the spread ability method according to ADA specification $\mathrm{N}^{0} 57$. Following this specification, the spread ability or extensibility method was defined by Ricci et al. ${ }^{29}$ as the average area obtained when the obturator cement is subjected to a constant load for a given time. This method refers to the ability to flatten or flatten the surface of a preparation when subjected to a particular force. It also refers to the ease with which it spreads and extends under pressure. ${ }^{28}$ The difference between the smallest and largest diameters shall not exceed $1.0 \mathrm{~mm}$ and the disc shall be uniformly circular. Otherwise, the test should be repeated following the same experimental parameters. Five repetitions should be performed for the studied cement, obtaining the arithmetic mean that represents the flow of the material. ${ }^{27}$ The minimum value recommended by ANSI/ADA is $20.0 \mathrm{~mm}$.

In the present study, the flow values were variable and are above the minimum recommended by ANSI/ADA (2000). However, the mean diameter of group $1(90 \%$ AH Plus $+10 \%$ MTA) was $41.1 \mathrm{~mm}$. The material taken from AH Plus paste B was found to be very fluid. This average value suggests the risk of cement leakage to the peri-apex, increasing the risk of periapical inflammation. This result may be justified by the fact that the first group used AH Plus cement at the beginning of the tubes. As can be seen from the study by Baldin et al., in which differences in physicochemical properties such as hardening time, fluidity and radiopacity at the beginning, middle and end of the tubes were noted. Thus demonstrating that $\mathrm{AH}$ Plus cement is not uniform and changes its consistency throughout the tubes: it is more fluid at the beginning and thicker at the end. ${ }^{36}$

The proportion of group 2 (80\% AH Plus + 20\% MTA) had a mean value of $32.86 \mathrm{~mm}$. The proportion of group 3 (70\% AH Plus + 30\% MTA) averaged 21.91. With diameters close to the minimum recommended by the ADA and without statistical differences when compared to Group 4 (AH Plus). AH Plus flow studies have shown very variable values following ANSI/ADA or ISO 31, 28, 32,33 specifications. Duarte ${ }^{31}$ found a result of $40.25 \mathrm{~mm}$, whereas Almeida et al. ${ }^{33}$ presented the value and $43 \mathrm{~mm}$ for the flow from AH Plus. In our study, the mean value found in Group 4 (AH Plus) was $24.41 \mathrm{~mm}$. Örstavik ${ }^{34}$ described the importance of the cement powder/liquid ratio being properly specified by the manufacturers in order to have a clinical reproduction acceptable to dental surgeons. Reported that other properties may change, including biocompatibility. When the amount of more fluid material was present the flow values increased considerably, making it clear that segregation interfered with the powder/liquid ratio of the affected paste itself, as well as the ready cement, thus affecting the flow values. McComband Smith ${ }^{35}$ stated that there is still no ideal value for the flow of endodontic cements, but these values cannot be excessive. Cements that have very high yield values increase the likelihood of cement leakage to the peri-apex. ${ }^{5,27}$ This cement extravasation to the peri-apex, keeping the cement in contact with periapical tissues, may lead to permanent inflammatory process. ${ }^{34}$

Specification $\mathrm{N}^{0} 57$ states that in flow tests, the disk formed must be at least $20 \mathrm{~mm}$ in diameter. Siqueira ${ }^{28}$ emphasizes that the good flow of na endodontic cement plays na important role in its penetration into the confined areas of the root canals. Thus, the cement must flow into the root canal system penetrating the minimum spaces not occupied by the solid material, becoming an important factor for the hermetic sealing. According to Allan et al. ${ }^{6}$ hardening time is an important property, as it indicates the time interval available for 
filling after material handling. Ideally, this should not be too short a time, so as not to hinder clinical practice, nor so long as to favor the release of irritants. The most frequently used method for determining curing time is by using Gillmore needles placed on the cement surface. A material is considered to have become trapped when these needles, when exerting only their own weight, do not leave marks on its surface. ${ }^{27}$ The hardening time of group 1 (AH Plus ${ }^{\circledR}+10 \%$ MTA) was 1631 minutes, very long time, contact with periapical tissues may cause irritation in this region before material set.

During the removal of the material inside the $\mathrm{AH}$ Plus ${ }^{\circledR}$ tubes, it was observed that the material coming out of the B-tube tube was more fluid, suggesting that the material had segregated inside it. In the present study it was found that the presentation of the inhomogeneous paste $B$ caused a change, increasing the hardening time.

The hardening time of groups $2(20 \%$ MTA $)$ and 3 (30\% MTA) were similar to that obtained in group 4 $\left(\mathrm{AH}\right.$ Plus ${ }^{\circledR}$ ), suggesting that the addition of MTA in the proportions of $10 \%, 20 \%$ and $30 \%$. do not change the hard- ening time of AH Plus cement. According to Marques ${ }^{36}$ MTA Fillapex ${ }^{\circledR}$ has high fluidity and may compromise its clinical performance, as it increases the chance of extravasation during obturation, which can lead to severe post-operative pain. Fillape ${ }^{\circledR}$ MTA in the present study had $26.47 \mathrm{~mm}$ flow and the cure time exceeded 6 weeks. In his study, Grossman ${ }^{27}$ stated that the ideal setting time hás not yet been determined but stated that this time should be sufficient for the dentist to fill the molar teeth with ease. According to verbal contact with the product manufacturers, the ANSI/ADA 57 standardization does not include bioceramic cements, requiring an adequate methodology to evaluate such properties.

\section{Conclusion}

Therefore, considering the results obtained and according to the methodology employed, it is concluded that: addition of $10 \%$ and $20 \%$ MTA to AH Plus did not affect the physicochemical properties of the obturator cements. Fill MTA Fillapex hás not been arrested in 6 weeks.

\section{References}

1. Soares IJ, Goldberg F. Endodontia: técnicas e fundamentos. $2^{\mathrm{a}}$ ed. Porto Alegre: Artimed, 2011.

2. Schilder H. Filling root canal in three dimensions. Det Clin North Am. 1976; 11 (3): 723-44.

3. Aznar FDC, Bueno CES, Nishiyama CK, Martin AS. Radiopacidade de sete cimentos endodônticos avaliada através de radiografia digital. RGO - Rev Gaúcha Odontol. 2010; 58(2):181-184.

4. Johnson WT, Guttmann JL. Obturation of cleaned and shaped root canal system. In: Cohen S, Hargreaves K. Pathways of the pulp. 9. ed. Philadelphia: Elsevier; 2007.

5. Alan NA, Walton RE, Shaffer M. Setting time for endodontic sealers under clinical usage and in vitro conditions. J Endod 2001; 27(6):421-3.

6. AH Plus: material de selamento de canais radiculares. Konstanz: DENTSPLY, 2005.

7. Assmann E. Avaliação da resistência da união à dentina dos cimentos a base de MTA e a base de resina epóxica, através do teste de micro push-out [Tese]. Porto Alegre: Universidade Federal do Rio Grande do Sul, 2010.

8. Torabinejad M, Hong CU, McDonald F, Pitt Ford TR. Physical and chemical propeties of a new root-end filling material. J Endod. 1995; 21(7):349-53.

9. Asgary S, Parirokh M, Eghbal MJ, Brink F. Chemical differences between white and gray mineral trioxide aggregate. J Endod 2005; 31(2):101-103.

10. Favieri A, Campos LC, Burity VH, Cecilia MS, Abad EC. Use of biomaterials in periradicular surgery: a case report. J Endod. 2008;34(4):490-4 11. Torabinejad M, Hong CU, McDonald F, T. R. Pitt Ford TR (1995) Physical and chemical properties of a new root-end filling material. Journal of Endodontics. 1995; 21(4): 349-53.

12. Santos AD, Moraes JC, Araújo EB, Yukimitu K, Valério WV. Int. Endodontic J. 2005; 38:443-447.

13. Dammaschke T, Gerth HUV, Zuchner H, Schafer E. Dental Mater. 2005; 21:731-738.

14. Camilleri J. Characterization of hydration products of mineral trioxide aggregate. Int. Endodontic J. 2008; 41(10):843-849.

15. Roberts HW, Toth JM, Berzins DW, Charlton DG. Mineral trioxide aggregate material use in endodontic treatment: a review of the literature. Dental Mater. 2008;24(2):149-164.

16. Koh ET, Torabinejad M, Pitt Ford TR, Brady K, McDonald F. Journ Biomedical Mater Res. 1997;(37):432-439.

17. P. J. Mitchell, T. R. Pitt Ford, M. Torabinejad, F. McDonald, Biomater. 1999;(20):167-173.
18. Koh ET, Mcdonald F, Pitt Ford TR, Torabinejad M. Cellular response to Mineral Trioxide Aggregate. J Endod. 1998; 24(8): 543-547.

19. E. A. Bortoluzzi, N. J. Broon, C. M. Bramante, A. Consolaro, R. B. Garcia, I. G. Moraes, N. Bernardineli. J Endodontics. 2008;(34):172-175.

20. Ber BS, Hatton JF, Stewart GP. J Endodontics. 2007; (33): 1231-1234.

21. Pandolfelli VC, Oliveira IR, Rossetto HL, Jacobovitz M. "Composição à base de cimento aluminoso para aplicações em endodontia e produto cimentício obtido", Registro de patente INPI 0704502-6, Universidade Federal de S. Carlos, SP (2007).

22. Bortoluzzi EA, Araújo GS, Guerreiro JM, Tanomaru M. J Endodontics. 2007; 33(3):325-327.

23. M. Jacobovitz, R. K. P. de Lima, Treatment of inflammatory internal root resorption with mineral trioxide aggregate: a case report. Int Endodontic J. 2008(41):905-912.

24. Oliveira IR, Pandolfelli VC. (2011). Propriedades e bioatividade de um cimento endodôntico à base de aluminato de cálcio. Cerâmica. 2011; 57(343): 364-370.

25. Accorinte MLR, Holland R, Reis A, Bortoluzzi MC, Murata SS, dezan Jr E, et al. Evaluation of Mineral Trioxide Aggregate and calcium hydroxide cement as pulp-capping agents in human teeth. J Endod. 2008;34:1-6.

26. Grosmann LI. Physical properties of root canal cements. J. Endod 1976; 2 (6): 166-75.

27. Siqueira JF. Antimicrobial activity and flow rate of newer and estabilished root canal sealers. J Endod. 2000; 26(5).

28. Lara EHG. Estudo do comportamento de algumas preparações básicas de dentifrícios na forma de pasta: I - Tecnologia. II- Propriedades reológicas. III Índice de abrasividade[Tese]. Ribeirão Preto: Universidade de São Paulo, 1988. 29. Ricci HP, Sinnnecker MM, Erdaneta J, León G. En busca de una especificacion para dentifrícios. Centro Nacional de Materiales Dentales de Caracas- Venezuela. Boletim anual 1975; 5(5).

30. Duarte MAH. Avaliação de algumas propriedades físico-químicas do cimento AH Plus puro e acrescido de hidróxido de cálcio [tese].Bauru(SP): Faculdade de Odontologia de Bauru, Universidade de São Paulo, 1999.

31. Versiani MA, Carvalho-Junior JR, Padilha MI, Lacey S, Pascon EA, Souza-Neto MD. A comparative study of physicochemical properties of AH Plus $^{\mathrm{TM}}$ and Epiphany ${ }^{\mathrm{TM}}$ root canal selants. Int Endod J 2006; 39 (6): 464-71.

32. Almeida JFA, Gomes BP, FERRAL CC, SOUZA FJ FILHO, Zaia AA. Filling of artificial lateral canals and micro leakage and flow of five endodontic seofers. IntEndad I. 2007; 40 (9): 692-9. 
33. Örstaviki D, Mijör IA. Histopathology and x-ray microanalysis of the subcutaneous tissue response to endodontic sealers. J Endod. 1988; 14 (1): 13-23.

34. McComb D, Smith DC. Comparison of physical properties of polycarboxylate-based and conventional root canal selars. J Endod, 1976; 2 (8) 228-35.
35. Marques NCT, Lourenço Neto N, Fernandes AP, Rodini CO, Duarte MAH, Oliveira TM. Rat subcutaneous tissue response to MTA Fillapex ${ }^{\circledR}$ and Portland Cement $^{\circledR}$. Braz Dent J 2013; 24(1):10-4.

36. Baldin JV, Bernardes RA, Duarte MA, Ordinola-Zepata R, Cavenago BC, Moraes JC, de Moraes IG. IntEndod J. 2012 Oct; 45(10): 915-20.

\section{Mini Curriculum and Author's Contribution}

1. Wanderson Carvalho de Almeida - Undergraduate student of Dentistry. Contribution: effective scientific and intellectual participation for the study; data acquisition, data interpretation; preparation and draft of the manuscript. ORCID: 0000-0001-5889-5490.

2. Barbara Manuelle de Carvalho Barros - Undergraduate student of Dentistry. Contribution: effective scientific and intellectual participation for the study; data acquisition, data interpretation; preparation and draft of the manuscript. ORCID: 0000-0003-4520-6945.

3. Isabelle de Meneses Aragão Ramos - Undergraduate student of Dentistry. Contribution: effective scientific and intellectual participation for the study; data acquisition, data interpretation; preparation and draft of the manuscript. ORCID: 0000-0002-8865-0213.

4. Maria Ângela Arêa Leão Ferraz - DDS; PhD. Contribution: effective scientific and intellectual participation for the study; data acquisition, data interpretation; preparation and draft of the manuscript critical review and final approval. ORCID: 0000-0001-5660-0222.

5. Carlos Alberto Monteiro Falcão - DDS; PhD. Contribution: effective scientific and intellectual participation for the study; data acquisition, data interpretation; preparation and draft of the manuscript critical review and final approval. ORCID: 0000-0001-7787-0280.

Submitted: 10/30/2019 / Accepted for publication:12/09/2019

Corresponding author

Wanderson Carvalho de Almeida

E-mail: wangstron@gmail.com 